\title{
QUEEN'S
UNIVERSITY
BELFAST
}

\section{Regenerating CNS myelin: Emerging roles of regulatory T cells and CCN proteins}

\author{
Gallardo, N. D. L. V., Dittmer, M., Dombrowski, Y., \& Fitzgerald, D. C. (2018). Regenerating CNS myelin: \\ Emerging roles of regulatory T cells and CCN proteins. Neurochemistry International. \\ https://doi.org/10.1016/j.neuint.2018.11.024
}

\section{Published in:}

Neurochemistry International

\section{Document Version:}

Peer reviewed version

\section{Queen's University Belfast - Research Portal:}

Link to publication record in Queen's University Belfast Research Portal

\section{Publisher rights}

Copyright 2018 Elsevier.

This manuscript is distributed under a Creative Commons Attribution-NonCommercial-NoDerivs License

(https://creativecommons.org/licenses/by-nc-nd/4.0/), which permits distribution and reproduction for non-commercial purposes, provided the author and source are cited.

\section{General rights}

Copyright for the publications made accessible via the Queen's University Belfast Research Portal is retained by the author(s) and / or other copyright owners and it is a condition of accessing these publications that users recognise and abide by the legal requirements associated with these rights.

Take down policy

The Research Portal is Queen's institutional repository that provides access to Queen's research output. Every effort has been made to ensure that content in the Research Portal does not infringe any person's rights, or applicable UK laws. If you discover content in the Research Portal that you believe breaches copyright or violates any law, please contact openaccess@qub.ac.uk. 


\section{Accepted Manuscript}

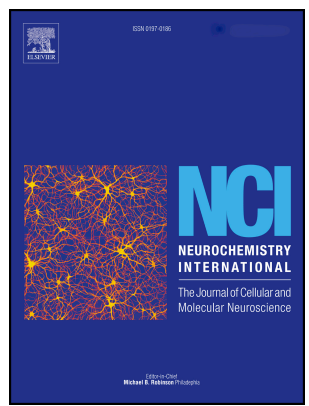

PII:

$$
\text { S0197-0186(18)30299-7 }
$$

DOI: $\quad$ https://doi.org/10.1016/j.neuint.2018.11.024

Reference: $\quad \mathrm{NCl} 4349$

To appear in: Neurochemistry International

Received Date: 30 June 2018

Revised Date: 19 November 2018

Accepted Date: 30 November 2018

Please cite this article as: Gallardo, N.d.I.V., Dittmer, M., Dombrowski, Y., Fitzgerald, D.C., Regenerating CNS myelin: Emerging roles of regulatory T cells and CCN proteins, Neurochemistry International (2019), doi: https://doi.org/10.1016/j.neuint.2018.11.024.

This is a PDF file of an unedited manuscript that has been accepted for publication. As a service to our customers we are providing this early version of the manuscript. The manuscript will undergo copyediting, typesetting, and review of the resulting proof before it is published in its final form. Please note that during the production process errors may be discovered which could affect the content, and all legal disclaimers that apply to the journal pertain. 


\title{
Regenerating CNS myelin: emerging roles of regulatory $\mathrm{T}$ cells and CCN proteins
}

\section{Author names and affiliations}

Nira de la Vega Gallardo, Marie Dittmer, Yvonne Dombrowski, Denise C. Fitzgerald

Wellcome Wolfson Institute for Experimental Medicine, School of Medicine, Dentistry and Biomedical Science, Queen's University Belfast, Northern Ireland, UK

\section{Corresponding author}

Denise C. Fitzgerald, d.fitzgerald@qub.ac.uk

\begin{abstract}
Efficient myelin regeneration in the central nervous system (CNS) requires the migration, proliferation and differentiation of oligodendrocyte progenitor cells (OPC) into myelinating oligodendrocytes. In demyelinating diseases such as multiple sclerosis (MS), this regenerative process can fail, and therapies targeting myelin repair are currently completely lacking in the clinic. The immune system is emerging as a key regenerative player in many tissues, such as muscle and heart. We recently reported that regulatory T cells (Treg) are required for efficient CNS remyelination. Furthermore, Treg secrete $\mathrm{CCN} 3$, a matricellular protein from the $\mathrm{CCN}$ family, implicated in regeneration of other tissues. Treg-derived CCN3 promoted oligodendrocyte differentiation and myelination. In contrast, previous studies showed that CCN2 inhibited myelination. These studies highlight the need for further scrutiny of the roles that CCN proteins play in myelin development and regeneration. Collectively, these findings open up exciting avenues of research to uncover the regenerative potential of the adaptive immune system.
\end{abstract}

\section{Highlights}

- Adaptive immune cells are emerging as key regulators of tissue regneration

- Treg support oligodendrocyte differentiation and remyelination

- CCN3 enhances oligodendrocyte differentiation and myelination

- CCN family of proteins may hold therapeutic potential for neurological dieases

\section{Keywords (up to 6)}

Treg, CCN3, remyelination, oligodendrocyte, regeneration

\section{Abbreviations}


$\mathrm{CCN}$

CIA

CNS

CT

CTGF

CYR61

EAE

ECM

GNP

HFSC

IDO

IGFBP

iTreg

MS

NOV

nTreg

OB

OPC

pTreg

RPE

SP

SRF

$\mathrm{Tg}$

Th

Treg

TSP1

VWC
CYR61 (CCN1), CTGF (CCN2), NOV (CCN3)

collagen-induced arthritis

central nervous system

C-terminal domain

connective tissue growth factor / CCN2

cysteine-rich angiogenic protein 61 / CCN1

experimental autoimmune encephalomyelitis

extracellular matrix

granule precursor neuron

hair follicle stem cells

indoleamine 2,3-dioxygenase

insulin-like growth factor-binding proteins

induced Treg

Multiple Sclerosis

nephroblastoma overexpressed / CCN3

natural Treg

olfactory bulb

oligodendrocyte progenitor cells

peripheral Treg

retinal pigment epithelium

signal peptide

serum response factor

transgenic

Thelper

regulatory $\mathrm{T}$ cells

type 1 repeat of thrombospondin

type $\mathrm{C}$ repeat of von Willebrand factor 


\section{Acknowledgements}

This work was supported by the Fritz Thyssen Foundation (10.17.2.014MN, to Y.D.), the Biotechnology and Biological Sciences Research Council (BB/J01026X/1, to D.C.F.) and Wellcome Trust (110138/Z/15/Z, to D.C.F.).

\section{Declarations of interest}

The authors declare that they have no competing interests. 


\section{Regenerative immunology}

The roles of T cells in inflammatory demyelinating diseases such as Multiple Sclerosis (MS) have been well-studied in recent decades. These research efforts have resulted in the development of around a dozen disease-modifying therapies for MS, many of which target T cell development, function and trafficking. Animal models of T cell-mediated demyelination have underpinned much of this research and the range of models of experimental autoimmune encephalomyelitis (EAE) have become the most widely used models, not only of MS, but of autoimmune disease in general. As such, neuroimmunology research has greatly informed inflammation biology in general. Among some of the key advances that have resulted from EAE studies are the pathogenic functions of effector $T$ helper (Th)1 and Th17 cells and the potent immunoregulatory capacity of suppressor T cells, more commonly now referred to as regulatory T cells (Treg) (Legroux and Arbour, 2016). These cells are potent anti-inflammatory cells that can target a range of inflammatory mechanisms (Kitagawa and Sakaguchi, 2017). However, as will be discussed later, Treg exert more than just anti-inflammatory influence. Recent studies have pinpointed a variety of Treg mechanisms that directly and indirectly boost tissue regeneration, opening up new avenues for the development of regenerative therapeutics based on T cell biology.

The topic of regenerative immunology is an emerging, and rapidly progressing field. The roles of immune responses in tissue regeneration can be largely categorised into mechanisms that support resolution of inflammation, which can indirectly support tissue regeneration, and direct regenerative mechanisms affecting non-immune cells such as stem and progenitor cells locally. Given the capacity for immune cells to exert such effects, the immune system holds immense potential to promote tissue regeneration. If we understand how the immune system naturally supports efficient tissue regeneration, this knowledge can be harnessed to develop new regenerative therapies. It is clear that the immune system can also be inhibitory to tissue regeneration and promote scarring and fibrosis, or even sustain immunopathological damage. In this regard, blocking immune signals that impair regenerative responses also holds therapeutic potential to promote regeneration.

In the field of regenerative immunology, influences of innate immune responses are perhaps better understood at this point, though several recent discoveries have shone a light on the adaptive immune system in tissue regeneration (Aurora and Olson, 2014). In particular, T lymphocytes have emerged as key cellular players that can influence tissue regeneration, both positively and negatively. This review will focus on an anti-inflammatory subset of $\mathrm{CD}^{+} \mathrm{T}$ cells that has gained much attention in regenerative biology, regulatory $T$ cells. 


\subsection{Regulatory T cells (Treg)}

T cells that suppress immune responses can be attributed to a range of subsets including $C D 8^{+} T$ cells and NKT cells but by far the most well understood are $\mathrm{CD} 4^{+}$Treg. Even within the $\mathrm{CD} 4^{+} \mathrm{T}$ cell subset there are a range of suppressive cells such as $\operatorname{Tr} 1$ and $\operatorname{Th} 3$ cells, however the suppressive T cell subset known as Treg express the canonical Treg marker Foxp3, a key defining feature of the Treg subset, will be discussed henceforth. It is important to note that suppressive cells such as $\operatorname{Tr} 1$, Th3 and suppressive cells of other lineage types do not express Foxp3 and thus, Foxp3 is not essential for suppressive function. Similarly, cells can express Foxp3 but not demonstrate suppressive function. There exist cells that co-express Foxp3 and other $\mathrm{CD}_{4}{ }^{+}$subset canonical transcription factors such as T-bet or RORyt (Ayyoub et al., 2009; Hall et al., 2013; Oldenhove et al., 2009), however these cell types have largely not been studied in regeneration. Thus, the $\mathrm{CD}^{+}$subsets of Treg that arise from canonical Foxp3 expression are the focus of this review. These subsets can arise directly during thymic development or be induced in peripheral tissues or in vitro. Cells that leave the thymus expressing CD4 and Foxp3 are referred to as natural Treg (nTreg) and those that arise in the periphery, from naïve $\mathrm{CD}^{+}$cells that are induced to express Foxp3 upon stimulus are known as induced Treg (iTreg) or peripheral Treg (pTreg). Treg generated from $\mathrm{CD}^{+}{ }^{\top} \mathrm{T}$ cells in vitro, generally using combinations of TCR activation, co-stimulation, TGF- $\beta$, IL-2 and anti-IFN- $\gamma$ are also referred to as iTreg. There are emerging tissue-specific subsets of Treg such as visceral adipose tissue Treg that have distinct profiles compared to circulating Treg. However, the functional commonality in all these subsets is the capacity to suppress immune responses.

While several cell surface and intracellular markers are associated with Treg identification, it is the suppressive nature of these cells that is the functional hallmark of Treg. Suppressive T cells were first proposed in the 1970 s as a subset of lymphocytes that could negatively regulate inflammatory responses (Benacerraf et al., 1975; Gershon and Kondo, 1970). The concept of suppressive T cells largely fell out of favour for quite some time but gained resurgence in the 1990s (Sakaguchi et al., 1995). The identification of Foxp3 as the canonical transcription factor driving Treg development (Fontenot et al., 2003; Hori et al., 2003) accelerated a field that uncovered immunoregulatory functions of Treg at an astounding pace. Treg were identified to inhibit the actions of virtually all pro-inflammatory immune cells including $T$ and B lymphocytes, dendritic cells and macrophages. Mechanisms of suppression included secretion of soluble factors (e.g. IL-10, TGF- $\beta$ and IL-35), cellcontact-dependent actions, direct cytolysis (e.g. granzyme-mediated killing), competition for proinflammatory signals needed to initiate and/or sustain pro-inflammatory immune responses (e.g. IL- 
2, CD80/CD86, MHC-II) and inhibition of antigen presenting cell maturation (reviewed in Shevach, 2018). Many of these mechanisms can indirectly support tissue regeneration by quelling the inflammatory response to tissue damage and providing a microenvironment supportive of regenerative mechanisms. Based on recent studies, this occurs in a range of tissues, however, there is growing evidence that Treg can also deliver direct signals to non-haematopoietic stem and progenitor cells to drive local tissue regeneration and functional recovery.

\subsection{Role of Treg in tissue regeneration}

A number of groups have now convincingly demonstrated mechanisms of how Treg support tissue regeneration and a picture is emerging of both tissue-specific anti-inflammatory as well as directly regenerative mechanisms, that can each promote tissue repair. Studies that identified a role for Treg in regeneration through control of inflammation include tissues of the retina, kidney and skin. In a model of renal ischaemia/reperfusion injury, depletion of Treg in vivo augmented kidney damage and mortality (Gandolfo et al., 2009). In a mouse model of oxygen-induced retinopathy, immunoregulatory functions of Treg have been shown to promote vascular repair (Deliyanti et al., 2017). Treg have also been identified to promote skin wound healing as depletion of Treg in vivo delayed wound closure and affected blood vessel maturation (Haertel et al., 2018; Nosbaum et al., 2016).

Treg have been shown to directly support regeneration of skeletal muscle, myelin, lung, myocardium, bone, and hair follicles (discussed in more detail below). Within these tissues different Treg cellular mechanisms and soluble factors have been implicated in accomplishing effective tissue regeneration. This is not surprising considering the diversity of progenitor cells in these different tissues and the distinct mechanisms that govern responses of these different cell types to damage in the respective tissue type (see Figure 1). Investigation of regenerative Treg mechanism in the central nervous system (CNS) will benefit from studies in other tissues which have been reported in recent years.

The groups of Mathis and Benoist elegantly revealed a role for Treg in muscle regeneration. Using a mouse model of cardiotoxin-induced muscle damage they showed that mice deficient in Treg showed impaired satellite cell differentiation and muscle regeneration. Furthermore, Treg-derived amphiregulin (AR) was critical in this setting (Burzyn et al., 2013). This group went on to show impaired Treg recruitment to lesioned muscle in aged mice, indicating that enhancing Treg recruitment may be a therapeutic goal to enhance tissue regeneration in the aged (Kuswanto et al., 
2016). In a similar sterile muscle injury setting, Castiglioni et al. observed that Treg directly increased the number of satellite cells and decreased the percentage of differentiated satellite cells in a Treg satellite cell co-culture model (Castiglioni et al., 2015). In a mouse model of myocardial infarction, depletion of Treg exacerbated cardiac inflammation and tissue damage while expansion of Treg in vivo using anti-CD28 superagonist after injury, reduced ventricular rupture and skewed monocytes/macrophages to a pro-regenerative M2-like phenotype (Weirather et al., 2014). Furthermore, the Frangogiannis group showed a direct effect of Treg on the cardiac fibroblast phenotype and function as Treg reduced the contraction of collagen pads by cardiac fibroblasts and reduced both $\alpha$-smooth muscle actin and MMP3 in an in vitro co-culture system (Saxena et al., 2014). Within the lung, Treg supported type II alveolar epithelial cell (AT2) proliferation and promoted lung epithelial barrier regeneration. Furthermore, KGF was identified as a critical Tregderived factor that drives AT2 cell proliferation (Dial et al., 2017; Mock et al., 2014). Skin-resident Treg directly promoted hair follicle stem cell (HFSC) regeneration via notch signaling through Treg Jagged1, which enhanced HFSC proliferation and differentiation (Ali et al., 2017). Treg have been shown to impact bone resorption, an important process in continuous skeletal remodeling. Foxp3overexpression, expansion of Treg numbers with CD28-specific superagonistic antibody or adoptive transfer of Treg into Rag1 ${ }^{-/}$mice resulted in increased bone mass and density due to decreased osteoclast numbers and decreased bone resorption (Zaiss et al., 2010b, 2010a). In addition, human Treg inhibited osteoclast differentiation via TGF- $\beta$ and IL-4 (Kim et al., 2007) and CTLA-4 was shown to regulate human osteoclast precursor numbers and osteoclastogenesis. Furthermore, engagement of CD80/86 through soluble CTLA-4 or co-culture with Treg inhibited osteoclast differentiation (Bozec et al., 2014). In 2017 we also uncovered a direct regenerative role for murine Treg in myelin regeneration in the CNS (Dombrowski et al., 2017), a tissue once thought to have very limited regenerative capacity. This emphasises the breadth and potency of regenerative Treg functions and opens new possibilities of developing neuroregenerative therapies, a key unmet need in neurological disease and ageing.

\section{Myelin regeneration}

Myelin is the protective coating around large diameter axons in the CNS that metabolically supports the underlying axon and enables fast, saltatory signal conduction (Fünfschilling et al., 2012; Lee et al., 2012). In the CNS, oligodendrocytes produce myelin sheaths with one oligodendrocyte having capacity to support over 40 myelin sheaths (Butt et al., 1994), while Schwann cells in the peripheral nervous system only ensheath one axon each (Geren and Schmitt, 1954). The complex functional network of oligodendrocyte-myelin extensions in the CNS is plastic and dynamic but also highly 
susceptible to damage by trauma or (auto)immune attacks, the latter a characteristic feature of many demyelinating diseases (Bradl and Lassmann, 2010; Young et al., 2013). Immune attacks can destroy entire myelin sheaths and kill oligodendrocytes leaving axons stripped bare and susceptible to neurodegeneration. MS is the most common demyelinating disease with around 2.5 million patients affected worldwide (Pugliatti et al., 2002). The hallmarks of this still incurable disease are demyelinated lesions throughout the brain, spinal cord and optic nerve as a result of immunemediated attacks against myelin; the underlying cause that triggers the disease, however, is still not well understood (Lassmann, 2014; Trapp et al., 1998).

Remyelination is a physiological process that efficiently replaces lost myelin throughout life in healthy individuals (Franklin and ffrench-Constant, 2017). Remyelination involves the recruitment of immature oligodendrocyte progenitor cells (OPC) to areas of damaged myelin, followed by proliferation and differentiation of OPC into myelin-producing oligodendrocytes that then extend newly formed myelin membranes around demyelinated axons (Franklin and Barnett, 1997). In demyelinating diseases such as MS, however, the regenerative capacity of oligodendrocytes declines with disease progression and can be lost entirely, leading to neurodegeneration and irreversible loss of function causing severe disability and morbidity for patients (Chang et al., 2002; Franklin and ffrench-Constant, 2008). Kuhlmann et al. uncovered oligodendrocyte differentiation failure as a key bottleneck for efficient remyelination in chronic MS lesions as demonstrated by the presence of proliferating OPC in up to $80 \%$ of non-remyelinating lesions (Kuhlmann et al., 2008). Others identified reduced numbers of OPC in the demyelinated lesions in both animal models and human demyelinated tissue (Boyd et al., 2013; Sim et al., 2002; Wolswijk, 2002) indicating that any of the above steps could be dysregulated in non-remyelinating lesions; the underlying mechanisms for successful remyelination, however, are still not completely understood.

Even beyond the CNS, tissue regeneration-promoting pharmacological agents hold immense potential to restore function and reduce morbidity and mortality in a range of diseases. Such regenerative therapies are largely lacking and stem cell-based therapies are a main area of focus in this regard. However any such therapy, be it cell-based or pharmacological, must function in a setting of tissue damage that is usually heavily influenced by robust immune responses to this damage. Thus, it is critical to understand the immunological players that influence tissue regeneration. Ageing is a universal impediment to efficient tissue regeneration and the global ageing 
population emphasizes the need to develop effective regenerative therapies, particularly in neurological disease.

While in the past two decades many disease-modifying therapies such as beta-interferon have been introduced to reduce relapse rates for many MS patients, these drugs are largely not effective for progressive MS and treatments that restore myelin remain experimental. This highlights the urgent need for remyelination therapies and recent experimental efforts have focused on identifying the cellular and molecular mechanisms driving myelin regeneration in order to identify novel remyelination targets. Numerous intrinsic and extrinsic factors that promote or inhibit OPC migration, proliferation and oligodendrocyte differentiation have been identified over the past two decades. These include growth factors such as PDGFa or activin-A, semaphorins, membrane proteins such as Lingo or CXCR2, interleukins such as LIF and CCN family members such as CCN3 (Dombrowski et al., 2017; Fischer et al., 2014; Lindner et al., 2008; Mi et al., 2007; Miron et al., 2013; Williams et al., 2007; Woodruff et al., 2004). Yet, these experimental approaches warrant confirmation of translational efficiency in clinical trials with MS patients. The use of high throughput screening methods has further accelerated the testing of preclinical remyelination drugs. Deshmukh et al. identified benztropine in OPC differentiation high throughput screening (Deshmukh et al., 2013), while Mei et al. identified clemastine as a potential remyelination drug using a micropillar screening approach (Mei et al., 2014). Njim et al. identified clobetasol and miconazole as remyelination promoting agents (Najm et al., 2015). Several remyelination approaches that were successful in preclinical models are being evaluated in clinical trials such as clemastine (Mei et al., 2014) in ReCOVER and ReBUILD (Plemel et al., 2017). Furthermore, cell-based therapies with bone marrow derived stem cells (ACTiMUS) and mesenchymal stem cells (MESEMS) are under investigation in phase I/II trials. However, the efficacy of these stem cell approaches is largely thought to be immunomodulatory. These studies demonstrate the growing range of approaches to develop regenerative therapies in MS (Plemel et al., 2017).

One of the most innovative approaches of new experimental remyelination methodologies is exploiting the capacity of the immune system to enhance tissue regeneration. This is particularly intriguing as immune cells, in particular T cells such as Th1 and Th17 cells, can orchestrate the immune-mediated attack leading to myelin damage in the CNS while cells of the innate immune system such as macrophages and microglia can execute and enhance myelin destruction (Baxi et al., 2015; Yamasaki et al., 2014). In MS, remyelination is associated with areas of inflammation; however if this is cause or correlation remains to be determined (Raine and Wu, 1993; Setzu et al., 2006). 
Nonetheless, experimental evidence suggests that inflammation is beneficial for remyelination and cells of both the innate and adaptive immune systems are required for efficient myelin regeneration (Arnett et al., 2003; Dombrowski et al., 2017; El Behi et al., 2017; Kotter et al., 2001; Miron et al., 2013; Patani et al., 2007; Ruckh et al., 2012; Schwartz et al., 1999). For instance, macrophages and microglia promote remyelination in animal models of MS (Doring et al., 2015; Kotter et al., 2001; Miron et al., 2013) and the lack of $B$ and T cells reduced remyelination efficiency in vivo (Bieber et al., 2003). Both B and T cell compartments consist of a variety of subtypes and in MS, Th1 and Th17 cells are implicated in disease pathology (Lassmann, 2014; Trapp et al., 1998), while Treg dampen immune responses by controlling inflammatory effector T cells. This diversity of T cell function has been demonstrated in both MS and associated animal models (Constantinescu et al., 2011; Costantino et al., 2008; Plaisted et al., 2016; Sakaguchi, 2000; Setzu et al., 2006; Sospedra and Martin, 2016). Yet for over a decade it remained unclear which lymphocyte population was the key cell type necessary for remyelination as reported previously (Bieber et al., 2003). However, with major advances in anti-inflammatory MS therapies during this time it was not surprising that the focus shifted somewhat away from this initial discovery. Recently, we have identified a key role of Treg in remyelination beyond known immunomodulatory functions of these cells (Dombrowski et al., 2017). In MS, Treg frequency is similar to that of healthy individuals, though Treg suppressor function is impaired (Viglietta et al., 2004). Furthermore, lymphocytes from MS patients differentially promote oligodendrocyte proliferation in a mouse model of demyelination (El Behi et al., 2017). Treg were described in regeneration of other tissues (discussed earlier) and are important for recovery from experimental spinal cord injury (Raposo et al., 2014), furthermore, we showed that Treg directly regulate a regenerative process in the CNS.

To categorically distinguish between Treg modulation of inflammatory myelin damage and the function of Treg in myelin regeneration we used an experimental model of MS that clearly distinguishes de- and remyelination phases. Injection of lysolecithin toxin directly into spinal cord white matter induces a focal lesion of demyelination which spontaneously and efficiently remyelinates during the following month (Hall, 1972). The regenerative phase in this model is well characterised and follows the steps of OPC recruitment into the lesion, differentiation of OPC into myelin-producing oligodendrocytes and finally, remyelination - wrapping and compaction of myelin around demyelinated axons (Hall, 1972). The well-defined timecourse of myelin regeneration in this model allows separation of damaging and regenerative phases, which is not possible in the commonly used experimental autoimmune encephalomyelitis (EAE) model, where de- and 
remyelination can happen concomitantly. Thus, it is not easy to distinguish the stage of lesion derived from EAE tissue; demyelinated, demyelinating, remyelinating or remyelinated lesions. Using the lysolecithin model we found that Treg were required for efficient remyelination as mice lacking Treg had significantly fewer remyelinated axons. This correlated with reduced numbers of differentiated oligodendrocytes in the lesions of these mice, indicating that Treg impact the critical step of oligodendrocyte differentiation (Dombrowski et al., 2017). This effect was mediated by the Treg secretome as Treg-conditioned media enhanced OPC differentiation in vitro but had no impact on OPC proliferation (Dittmer et al., 2018; Dombrowski et al., 2017). Treg secretome screening revealed CCN3 as a protein highly enriched in Treg-conditioned media but not in that from Foxp3 ${ }^{-} \mathrm{T}$ cells. In vitro neutralisation and depletion studies identified CCN3 as a factor that mediated the promyelinating Treg effect (Dombrowski et al., 2017) (see Figure 2). This not only identified CCN3 as a protein targeting OPC differentiation but was also the first report that described CCN3 production in Treg, or indeed any T cells. This extends the known immunomodulatory role of Treg in the CNS to now include myelin regenerative functions. How our findings translate to human MS remains to be uncovered.

\section{CCN proteins}

CCN3 belongs to a family of matricellular proteins known as the CCN family, largely associated with the extracellular matrix (ECM) and involved in a wide range of biological signaling pathways. The family was named after the original nomenclature given to the first three identified members, in chronological order: Cysteine-rich angiogenic protein 61 (CYR61), Connective tissue growth factor (CTGF) and Nephroblastoma overexpressed (NOV) - now known as CCN1, CCN2 and CCN3 respectively (Joliot et al., 1992; O'Brien et al., 1990; Ryseck et al., 1991). These proteins were unified in nomenclature after it was observed that they shared similar structural features (Bork, 1993). Thereafter, three more members were identified. These peptides were initially named Wnt-1 Inducible Signaling Pathway Proteins 1-3 (WISP 1-3), and later changed to CCN4, CCN5 and CCN6 respectively (Brigstock et al., 2003; Hashimoto et al., 1998; Pennica et al., 1998; Zhang et al., 1998). Regardless of the structural similarities, these proteins carry out very distinct and sometimes opposing functions depending on the protein and tissue in question. 
The primary peptide chain of CCN proteins contains 343-381 amino acids. These polypeptides can generate products of 35 to $40 \mathrm{kDa}$ in size (with larger molecular weight when subjected to post-translational modifications) consisting of 38 conserved cysteine amino acids, which are organized into four modules (Brigstock, 1999). From the primary amino acid sequences, it was observed that these modules shared similarity with Insulin-like growth factor-binding proteins (IGFBP), a type C repeat of von Willebrand factor (VWC), a type 1 repeat of thrombospondin (TSP1) and a C-terminal domain (CT) (Perbal, 2004) (see Figure 3). Additionally, there is a signal peptide (SP) located at the N-terminus of the proteins, which led to the finding that many CCN proteins are secreted (Perbal, 2013). Each of these modules is encoded by a distinct exon, and most CCN genes have five exons. Exceptions to this organization include CCN5, which lacks a CT domain, and CCN6, which lacks four of the conserved cysteine residues in the VWC module. The existence of a hinge region between VWC and TSP1 modules and reports that CCN2 is post-translationally modified into shorter isoforms (Ball et al., 1998), led to speculation that these proteins have the potential for proteolytic cleavage.

The functions carried out by CCN proteins are extremely diverse, and depending on the cell type, some functions can be antagonistic. These include differentiation, development, cell cycle control, tissue repair and regeneration, inflammation, connective tissue scarring (fibrosis), ECM synthesis and degradation, cell migration and adhesion (Perbal and Takigawa, 2005). Unsurprisingly, due to heavy involvement of CCN proteins in cell cycle control, these proteins play a critical role in many types of cancer - such as gastric, ovarian, breast, prostate, oesophageal, colorectal, bone and brain tumours (reviewed in Chen and Lau, 2009). It is worth noting that there is discussion regarding whether CCN functions are due to the action of individual modules or combinations of modules. Proteins can also form homomeric or heteromeric complexes with other $\mathrm{CCN}$ members or even proteins from other families, which adds complexity to the study of CCN family in the context of cell biology (discussed in Perbal, 2018).

\subsection{Roles of CCN proteins in the CNS}


There is substantial evidence that matricellular proteins play important roles in the CNS. Investigation into the expression and function of CCN proteins in the CNS is a developing field and sometimes contradictory. Nevertheless, the growing body of literature in this field provides an insight into CCN function in the CNS during development, adulthood, tissue damage and regeneration. Currently, there is evidence of expression and functions of CCN15 in the CNS but not yet for CCN6 (see Figure 4). CCN proteins are widely expressed in the developing and mature CNS (reviewed in Malik et al., 2015).

Evidence suggests that CCN1 is a positive regulator of dendritic arborisation in developing rat hippocampal neurons in vitro. CCN1 knockdown in developing neurons reduced dendritic arborisation and total dendritic length, however no effect was observed in mature neurons (Malik et al., 2013). Overexpression of CCN1 in both developing and mature neurons, increased dendrite numbers and CCN1 positively regulated this neuronal dendrite increase through $\beta 1$-integrin signaling (Malik et al., 2013). CCN1 has also been shown to play a role in hippocampal neuron progenitor cell death. Treatment of H19-7 hippocampal progenitor cells with the chemotherapeutic agent, etoposide, caused apoptosis and this was associated with CCN1 expression. CCN1 was upregulated in cell lysates of etoposide-treated cells at 510h post-treatment and secreted into the supernatant for up to $48 \mathrm{~h}$. Knockdown of the serum response factor (SRF) in these cells resulted in complete abrogation of etoposidemediated upregulation of CCN1, and blocking CCN1 expression in etoposide-treated cells led to increased survival of embryonic hippocampal neural progenitor cells (Kim et al., 2003). These findings demonstrated a role for CCN1 in neuronal apoptosis. Contrary to this, CCN1 has been described to promote retinal photoreceptor survival by interacting with Müller glia and the retinal pigment epithelium (RPE) by promoting Akt, ERK1, ERK2 and STAT3 phosphorylation. This phosphorylation was suggested to cause transcriptional changes in Müller glia and RPE, leading to the secretion of neuroprotective factors that directly affect photoreceptor cell survival (Kucharska et al., 2014).

CCN2 regulates inhibitory neuron survival in the glomerular layer of the olfactory bulb (OB) in postnatal mice. CCN2 was secreted by external tufted cells and decreased the survival of 
periglomerular inhibitory neurons by promoting apoptosis through TGF- $\beta 2$. Changes in CCN2 expression levels in the OB modified local neuronal circuitry and olfactory behaviours (Khodosevich et al., 2013). Recently, a negative regulatory role for CCN2 in CNS myelination has been elucidated, which will be discussed later.

CCN3 was shown to be expressed by Purkinje neurons and negatively regulated granule neuron precursor cell (GNP) proliferation during cerebellar development. CCN3 blocked sonic hedgehog (SHH)-mediated GNP proliferation through GSK3- $\beta$ activity, which in turn downregulated N-Myc, a driver of GNP proliferation. This anti-proliferative function of CCN3 in GNPs was attributed to interaction with integrins containing the $\beta 3$ subunit. In addition to modulating proliferation, this study reported that CCN3 stimulates GNP chemotaxis. Based on these findings, the authors hypothesised that CCN3 could be a potential player in GNP maturation (Le Dréau et al., 2010). CCN3 has also been reported to play a role in neurite growth inhibition in Neuro2A cells (Park et al., 2015) and to be expressed during chick retinal development mainly (but not exclusively) by Müller cells in vivo and in vitro. This expression was induced by BMP signalling and downregulated by Notch signalling in Müller cell cultures, and the authors discussed that CCN3 could play a role in Müller cell biology in the developing and adult retina (Maryvonne et al., 2012). Interestingly, CCN3 was found to have a positive role in oligodendrocyte differentiation and developmental myelination which will be discussed later in more detail (Dombrowski et al., 2017).

CCN4 was shown to prevent neuronal injury and apoptosis during oxidative stress exposure in vitro. CCN4 required activation of the PI3K and Akt1 pathways to enhance neuronal cell survival. Through these pathways, CCN4 promoted phosphorylation of Bad and GSK-3 $\beta$, reduced Bim/Bax and increased $\mathrm{Bcl}-\mathrm{xL} / \mathrm{Bax}$ complex expression. CCN4 prevented mitochondrial membrane permeability, cytochrome $c$ release, and caspase 3 activity in the presence of oxidative stress (Wang et al., 2012). These results suggest that CCN4 plays a role in neuronal survival. 
In contrast to CCN3, CCN5 was shown to promote neurite formation in Neuro2a cells. Recombinant CCN5 treatment induced Akt phosphorylation by interacting with integrin $\beta 1$. Moreover, CCN5 overexpression promoted neuronal survival in cells challenged with the neurotoxic agent $\mathrm{H}_{2} \mathrm{O}_{2}$ (Ohkawa et al., 2011). These results suggest that CCN5 may play a role in neurite formation and neuronal survival.

\subsection{Roles of CCN3 in tissue regeneration}

We reported a novel function of Treg-derived CCN3 in oligodendrocyte differentiation and myelination, supporting previous findings of CCN3 pro-regenerative functions in other tissues. CCN3 plays a role in inflammation resolution, which is crucial for efficient tissue regeneration. CCN3 acted as a negative regulator of vascular inflammation and promoted inflammatory response resolution in vascular endothelial cells and tissues (Lin et al., 2010; Liu et al., 2014; Zhang et al., 2016; Shi et al., 2017) as well as in the kidney (Marchal et al., 2015) and DRG neurons (Kular et al., 2012) suggesting that CCN3 can support efficient tissue regeneration via multiple mechanisms.

Direct injection of CCN3 into the rat cornea induced neovascularization demonstrating the pro-angiogenic function of this protein (Lin et al., 2003). CCN3 secreted from prostate cancer cells induced polarisation of M1-like macrophages to an M2-like phenotype, which is a key immunological switch that reduces inflammation and promotes tissue repair (Chen et al., 2014). Prostate cancer cell-derived CCN3 promoted focal adhesion kinase signaling, resulting in VEGF upregulation and tube formation by endothelial progenitor cells (Chen et al., 2014). CCN3 was identified to be essential for hematopoietic stem cell (HSC) renewal in humans. CCN3 is essential for maintaining HSC long term repopulating activity and bone marrow engraftment (Gupta et al., 2007). Finally, CCN3 is also known to participate in chondrogenesis (Heath et al., 2008; Hoshijima et al., 2012; Janune et al., 2017, 2011; Kawaki et al., 2008; Lafont et al., 2005; Roddy and Boulter, 2015), osteogenesis (Heath et al., 2008; Matsushita et al., 2013; Minamizato et al., 2007; Ouellet and Siegel, 2012; Rydziel et al., 2007) and dentin regeneration (Wang et al., 2014). 


\subsection{Roles of CCN2 and CCN3 in myelin development and regeneration}

For the first time, we found evidence that Treg-derived CCN3 enhances oligodendrocyte differentiation and myelination. Even though this is the case in ex vivo and in vitro models containing other cells from the CNS, CCN3 is dispensable for the direct effects of Treg on oligodendrocyte differentiation (our unpublished observations). This suggests that CCN3induced oligodendrocyte differentiation enhancement could be mediated through a different cell type such as microglia, neurons or astrocytes. Alternatively, CCN3 could interact with extracellular matrix components to facilitate enhanced OPC differentiation. As previously mentioned, neuron-derived CCN2 negatively regulates myelination. It was found that knocking out neuronal SRF in mice led to downregulation of myelin gene expression and myelination impairment. In this setting, CCN2 expression was upregulated, and this upregulation inhibited oligodendrocyte differentiation by blocking IGF1, a known enhancer of oligodendrocyte differentiation (Stritt et al., 2009). Supporting these findings, Tsc1 or Tsc2 knockdown in neurons led to a hypomyelination phenotype, similar to that observed in tuberous sclerosis patients. CCN2 was upregulated in neurons lacking Tsc1 and Tsc2 and it was proposed that this may be due to the downregulation of its transcription factor repressor SRF (Ercan et al., 2017). Finally, inhibiting neuronal CCN2 rescued hypomyelination in the setting of Tsc deficiency. This identified CCN2 as a neuronal regulator of myelination, and a target of the mTOR pathway (Ercan et al., 2017). More recently, it was demonstrated that treatment of hSOD ${ }^{\mathrm{G}}{ }^{\mathrm{GA}}$ mice (Amyotrophic Lateral Sclerosis mouse model) with a CCN2 neutralising antibody (FG-3019) delayed disease onset, improved locomotor function, decreased myofiber atrophy and increased neuromuscular junction innervation. Treatment of hSOD $1^{\text {G93A }}$ mice with FG-3019 also decreased myelin degeneration in the sciatic nerve compared to IgG-treated controls (Gonzalez et al., 2018). Taken together, these results demonstrate a negative regulatory role of CCN2 in myelination. Although some of the mechanisms behind the negative regulation of myelination by CCN2 have been elucidated, it remains unknown how CCN3 promotes oligodendrocyte differentiation and myelination. CCN3 exerts some of its biological functions through several receptors in non-CNS cells, including Notch1 (Sakamoto et al., 2002), integrins $\alpha 6 \beta 1, \alpha v \beta 3, \alpha v \beta 5$ and $\alpha 5 \beta 1$ (reviewed in Chen and Lau, 2009) and DDR1 (Fukunaga-Kalabis et al., 2006). These receptors are also found in cells of the central 
nervous system, therefore future in vitro studies should clarify which cells and receptors are involved in CCN3-mediated myelination enhancement. Likewise, in vivo murine models and human tissue investigations should determine whether CCN3 is a candidate of interest for remyelinating therapies.

Interestingly, CCN2 and CCN3 have been shown to exert reciprocal regulation of expression in different tissues. For instance, knocking out CCN2 in chondrocytes strongly upregulates CCN3 expression. This upregulation leads to a decrease in chondrocyte proliferation (Kawaki et al., 2008). CCN3 has also been reported to directly bind CCN2 and regulate the expression of cartilaginous matrix genes in a chondrosarcoma cell line (Hoshijima et al., 2012). CCN3 is robustly expressed in neurons of the adult and developing rodent CNS (Su et al., 2001; our unpublished observations), hence it is tempting to hypothesise that there is inter-regulation between neuronal CCN2 and CCN3 to control oligodendrocyte differentiation. Taken together, these findings reinforce the increasing evidence that ECM and ECM-associated components play a crucial role in OPC migration, proliferation and differentiation (Lau et al., 2013). This opens up an exciting avenue of research into CCN proteins for remyelination therapies.

\subsection{Conclusion}

The potential impact of regenerative therapies in neurological disease is vast and recent studies discussed here suggest that immune mechanisms may hold considerable potential to develop such therapies. Elucidating how immune cells naturally promote inflammatory lesion resolution, stem and progenitor development and ultimately, regeneration of functional tissue will provide knowledge to drive regenerative drug development programmes for therapeutic gain. The recent focus on the adaptive immune system, in particular T cells in regeneration, has pointed to a range of $\mathrm{T}$ cell mechanisms that benefit tissue regeneration. The diversity of mechanisms in varied tissues is striking and some common mechanisms in different tissues suggest that $\mathrm{T}$ cell-derived regenerative therapies may be applicable to a range of debilitating diseases. Some of these mechanisms discovered in peripheral tissues may well be relevant in the CNS, and this may accelerate the development of therapies for neurological disease including MS. However, it is imperative to study T cell-driven tissue regeneration in the CNS also, to ensure that CNS-specific T cell 
bioactivity is interrogated. The emergence of Treg as regenerative T cells, aligned to the multitude of ongoing Treg cell therapy-based clinical trials (both cell infusion and Treg expansion in vivo e.g. low dose IL-2) hints at a potential boon in therapeutic gain from a therapy that can both resolve inflammation and promote tissue regeneration. It will be fascinating to discover if such therapies indeed promote tissue regeneration and functional recovery in current and future trials in Multiple Sclerosis and other inflammatory diseases. If so, uncovering the underlying mechanisms in human systems will be of major importance in the fight against chronic disease. 


\section{Figure legends}

Figure 1: Role of Treg in tissue regeneration. Treg directly enhance regeneration of the lung, skeletal muscle, myocardium, CNS, bone and hair follicles and indirectly facilitate enhanced regeneration of kidney, retina/vasculature and wounded skin through immunomodulation.

Figure 2: Regenerative role of Treg in remyelination. Treg-derived factors, including CCN3, facilitate OPC differentiation and remyelination in the CNS.

Figure 3: General structure of CCN family members. Insulin-like growth factor-binding protein domain (IGFBP), type C repeat of von Willebrand factor domain (VWC), type 1 repeat of thrombospondin domain (TSP1), C-terminal domain (CT) and signal peptide (SP).

Figure 4: Role of CCN proteins in the CNS. CCN1-5 impact a variety of CNS processes including survival, proliferation, chemotaxis and differentiation of neurons and neural progenitors as well as OPC.

\section{References}

Ali, N., Zirak, B., Rodriguez, R.S., Pauli, M.L., Truong, H.A., Lai, K., Ahn, R., Corbin, K., Lowe, M.M., Scharschmidt, T.C., Taravati, K., Tan, M.R., Ricardo-Gonzalez, R.R., Nosbaum, A., Bertolini, M., Liao, W., Nestle, F.O., Paus, R., Cotsarelis, G., Abbas, A.K., Rosenblum, M.D., 2017. Regulatory T Cells in Skin Facilitate Epithelial Stem Cell Differentiation. Cell 169, 1119-1129.e11. https://doi.org/10.1016/j.cell.2017.05.002

Arnett, H.A., Wang, Y., Matsushima, G.K., Suzuki, K., Ting, J.P.-Y., 2003. Functional genomic analysis of remyelination reveals importance of inflammation in oligodendrocyte regeneration. J. Neurosci. 23, 9824-32. https://doi.org/23/30/9824 [pii]

Aurora, A.B., Olson, E.N., 2014. Immune modulation of stem cells and regeneration. Cell Stem Cell 15, 14-25. https://doi.org/10.1016/j.stem.2014.06.009

Ayyoub, M., Deknuydt, F., Raimbaud, I., Dousset, C., Leveque, L., Bioley, G., Valmori, D., 2009. Human memory FOXP3+ Tregs secrete IL-17 ex vivo and constitutively express 
the TH17 lineage-specific transcription factor ROR t. Proc. Natl. Acad. Sci. 106, 86358640. https://doi.org/10.1073/pnas.0900621106

Ball, D.K., Surveyor, G.A., Diehl, J.R., Steffen, C.L., Uzumcu, M., Mirando, M.A., Brigstock, D.R., 1998. Characterization of 16- to 20-kilodalton (kDa) connective tissue growth factors (CTGFs) and demonstration of proteolytic activity for 38-kDa CTGF in pig uterine luminal flushings. Biol. Reprod. 59, 828-35.

https://doi.org/10.1095/BIOLREPROD59.4.828

Baxi, E.G., DeBruin, J., Tosi, D.M., Grishkan, I. V., Smith, M.D., Kirby, L.A., Strasburger, H.J., Fairchild, A.N., Calabresi, P.A., Gocke, A.R., 2015. Transfer of Myelin-Reactive Th17 Cells Impairs Endogenous Remyelination in the Central Nervous System of Cuprizone-Fed Mice. J. Neurosci. 35, 8626-8639. https://doi.org/10.1523/JNEUROSCI.3817-14.2015

Benacerraf, B., Kapp, J.A., Debré, P., Pierce, C.W., de la Croix, F., 1975. The Stimulation of Specific Suppressor T Cells in Genetic Non-Responder Mice by Linear Random Copolymers of L-Amino Acids. Immunol. Rev. 26, 21-38. https://doi.org/10.1111/j.1600-065X.1975.tb00173.x

Bieber, A.J., Kerr, S., Rodriguez, M., 2003. Efficient central nervous system remyelination requires T cells. Ann. Neurol. 53, 680-684. https://doi.org/10.1002/ana.10578

Bork, P., 1993. The modular architecture of a new family of growth regulators related to connective tissue growth factor. FEBS Lett 327, 125-130. https://doi.org/00145793(93)80155-N [pii]

Boyd, A., Zhang, H., Williams, A., 2013. Insufficient OPC migration into demyelinated lesions is a cause of poor remyelination in MS and mouse models. Acta Neuropathol. 125, 841859. https://doi.org/10.1007/s00401-013-1112-y

Bozec, A., Zaiss, M.M., Kagwiria, R., Voll, R., Rauh, M., Chen, Z., Mueller-schmucker, S., Kroczek, R.A., Heinzerling, L., Moser, M., Mellor, A.L., David, J., Schett, G., 2014. T Cell Costimulation Molecules CD80 / 86 Inhibit Osteoclast Differentiation by Inducing the IDO / Tryptophan Pathway. Sci. Transl. Med. 6, 1-11. https://doi.org/10.1126/scitranslmed.3007764.T 
Bradl, M., Lassmann, H., 2010. Oligodendrocytes: Biology and pathology. Acta Neuropathol. 119, 37-53. https://doi.org/10.1007/s00401-009-0601-5

Brigstock, D.R., 1999. The Connective Tissue Growth Factor/Cysteine- Rich 61/Nephroblastoma Overexpressed (CCN) Family ${ }^{1}$. Endocr. Rev. 20, 189-206. https://doi.org/10.1210/edrv.20.2.0360

Brigstock, D.R., Goldschmeding, R., Katsube, K.I., Lam, S.C.T., Lau, L.F., Lyons, K., Naus, C., Perbal, B., Riser, B., Takigawa, M., Yeger, H., 2003. Proposal for a unified CCN nomenclature. J. Clin. Pathol. - Mol. Pathol. 56, 127-128. https://doi.org/10.1136/mp.56.2.127

Burzyn, D., Kuswanto, W., Kolodin, D., Shadrach, J.L., Cerletti, M., Jang, Y., Sefik, E., Tan, T.G., Wagers, A.J., Benoist, C., Mathis, D., 2013. A Special Population of regulatory T Cells Potentiates muscle repair. Cell 155, 1282-1295. https://doi.org/10.1016/j.cell.2013.10.054

Butt, A.M., Colquhoun, K., Tutton, M., Berry, M., 1994. Three-dimensional morphology of astrocytes and oligodendrocytes in the intact mouse optic nerve. J. Neurocytol. 23, 469-485. https://doi.org/10.1007/BF01184071

Castiglioni, A., Corna, G., Rigamonti, E., Basso, V., Vezzoli, M., Monno, A., Almada, A.E., Mondino, A., Wagers, A.J., Manfredi, A.A., Rovere-Querini, P., 2015. FOXP3+T cells recruited to sites of sterile skeletal muscle injury regulate the fate of satellite cells and guide effective tissue regeneration. PLoS One 10, 1-18. https://doi.org/10.1371/journal.pone.0128094

Chang, A., Tourtellotte, W.W., Rudick, R., Trapp, B.D., 2002. Premyelinating Oligodendrocytes in Chronic Lesions of Multiple Sclerosis. N. Engl. J. Med. 346, 165173. https://doi.org/10.1056/NEJMoa010994

Chen, C.-C., Lau, L.F., 2009. Functions and mechanisms of action of CCN matricellular proteins. Int. J. Biochem. Cell Biol. 41, 771-783. https://doi.org/10.1016/j.biocel.2008.07.025

Chen, P.-C., Cheng, H.-C., Wang, J., Wang, S.-W., Tai, H.-C., Lin, C.-W., Tang, C.-H., 2014. 
Prostate cancer-derived CCN3 induces M2 macrophage infiltration and contributes to angiogenesis in prostate cancer microenvironment. Oncotarget 5, 1595-608. https://doi.org/10.18632/oncotarget.1570

Constantinescu, C.S., Farooqi, N., O’Brien, K., Gran, B., 2011. Experimental autoimmune encephalomyelitis (EAE) as a model for multiple sclerosis (MS). Br. J. Pharmacol. 164, 1079-1106. https://doi.org/10.1111/j.1476-5381.2011.01302.x

Costantino, C.M., Baecher-Allan, C.M., Hafler, D.A., 2008. Human regulatory T cells and autoimmunity. Eur. J. Immunol. 38, 921-924. https://doi.org/10.1002/eji.200738104

Deliyanti, D., Talia, D.M., Zhu, T., Maxwell, M.J., Agrotis, A., Jerome, J.R., Hargreaves, E.M., Gerondakis, S., Hibbs, M.L., Mackay, F., Wilkinson-Berka, J.L., 2017. Foxp3+ Tregs are recruited to the retina to repair pathological angiogenesis. Nat. Commun. 8, 1-12. https://doi.org/10.1038/s41467-017-00751-w

Deshmukh, V.A., Tardif, V., Lyssiotis, C.A., Green, C.C., Kerman, B., Kim, H.J., Padmanabhan, K., Swoboda, J.G., Ahmad, I., Kondo, T., Gage, F.H., Theofilopoulos, A.N., Lawson, B.R., Schultz, P.G., Lairson, L.L., 2013. A regenerative approach to the treatment of multiple sclerosis. Nature 502, 327-332. https://doi.org/10.1038/nature12647

Dial, C.F., Tune, M.K., Doerschuk, C.M., Mock, J.R., 2017. Foxp3+ Regulatory T Cell Expression of Keratinocyte Growth Factor Enhances Lung Epithelial Proliferation. Am. J. Respir. Cell Mol. Biol. 57, 162-173. https://doi.org/10.1165/rcmb.2017-00190C

Dittmer, M., Young, A., O’Hagan, T., Eleftheriadis, G., Bankhead, P., Dombrowski, Y., Medina, R.J., Fitzgerald, D.C., 2018. Characterization of a murine mixed neuron-glia model and cellular responses to regulatory T cell-derived factors. Mol. Brain 11, 25. https://doi.org/10.1186/s13041-018-0367-6

Dombrowski, Y., O’Hagan, T., Dittmer, M., Penalva, R., Mayoral, S.R., Bankhead, P., Fleville, S., Eleftheriadis, G., Zhao, C., Naughton, M., Hassan, R., Moffat, J., Falconer, J., Boyd, A., Hamilton, P., Allen, I. V., Kissenpfennig, A., Moynagh, P.N., Evergren, E., Perbal, B., Williams, A.C., Ingram, R.J., Chan, J.R., Franklin, R.J.M., Fitzgerald, D.C., 2017. Regulatory T cells promote myelin regeneration in the central nervous system. Nat. 
Neurosci. 20, 674-680. https://doi.org/10.1038/nn.4528

Doring, A., Sloka, S., Lau, L., Mishra, M., van Minnen, J., Zhang, X., Kinniburgh, D., Rivest, S., Yong, V.W., 2015. Stimulation of Monocytes, Macrophages, and Microglia by Amphotericin B and Macrophage Colony-Stimulating Factor Promotes Remyelination. J. Neurosci. 35, 1136-1148. https://doi.org/10.1523/JNEUROSCI.1797-14.2015

El Behi, M., Sanson, C., Bachelin, C., Guillot-Noël, L., Fransson, J., Stankoff, B., Maillart, E., Sarrazin, N., Guillemot, V., Abdi, H., Cournu-Rebeix, I., Fontaine, B., Zujovic, V., 2017. Adaptive human immunity drives remyelination in a mouse model of demyelination. Brain 140, 967-980. https://doi.org/10.1093/brain/awx008

Ercan, E., Han, J.M., Di Nardo, A., Winden, K., Han, M.-J., Hoyo, L., Saffari, A., Leask, A., Geschwind, D.H., Sahin, M., 2017. Neuronal CTGF/CCN2 negatively regulates myelination in a mouse model of tuberous sclerosis complex. J. Exp. Med. 214, jem.20160446. https://doi.org/10.1084/jem.20160446

Fischer, R., Wajant, H., Kontermann, R., Pfizenmaier, K., Maier, O., 2014. Astrocyte-specific activation of TNFR2 promotes oligodendrocyte maturation by secretion of leukemia inhibitory factor. Glia 62, 272-283. https://doi.org/10.1002/glia.22605

Fontenot, J.D., Gavin, M.A., Rudensky, A.Y., 2003. Foxp3 programs the development and function of CD4+CD25+ regulatory T cells. Nat. Immunol. 4, 330-336. https://doi.org/10.1038/ni904

Franklin, R.J.M., Barnett, S.C., 1997. Do olfactory glia have advantages over Schwann cells for CNS repair? J. Neurosci. Res. 50, 665-672. https://doi.org/10.1002/(SICI)10974547(19971201)50:5<665::AID-JNR4>3.0.CO;2-F

Franklin, R.J.M., ffrench-Constant, C., 2017. Regenerating CNS myelin - from mechanisms to experimental medicines. Nat. Rev. Neurosci. 18, 753-769. https://doi.org/10.1038/nrn.2017.136

Franklin, R.J.M., ffrench-Constant, C., 2008. Remyelination in the CNS: from biology to therapy. Nat. Rev. Neurosci. 9, 839-855. https://doi.org/10.1038/nrn2480 
Fukunaga-Kalabis, M., Martinez, G., Liu, Z.-J., Kalabis, J., Mrass, P., Weninger, W., Firth, S.M., Planque, N., Perbal, B., Herlyn, M., 2006. CCN3 controls 3D spatial localization of melanocytes in the human skin through DDR1. J. Cell Biol. 175, 563-569. https://doi.org/10.1083/jcb.200602132

Fünfschilling, U., Supplie, L.M., Mahad, D., Boretius, S., Saab, A.S., Edgar, J., Brinkmann, B.G., Kassmann, C.M., Tzvetanova, I.D., Möbius, W., Diaz, F., Meijer, D., Suter, U., Hamprecht, B., Sereda, M.W., Moraes, C.T., Frahm, J., Goebbels, S., Nave, K.-A., 2012. Glycolytic oligodendrocytes maintain myelin and long-term axonal integrity. Nature 485, 517-21. https://doi.org/10.1038/nature11007

Gandolfo, M.T., Jang, H.R., Bagnasco, S.M., Ko, G.-J., Agreda, P., Satpute, S.R., Crow, M.T., King, L.S., Rabb, H., 2009. Foxp3+ regulatory T cells participate in repair of ischemic acute kidney injury. Kidney Int. 76, 717-729. https://doi.org/10.1038/ki.2009.259

Geren, B.B., Schmitt, F.O., 1954. THE STRUCTURE OF THE SCHWANN CELL AND ITS RELATION TO THE AXON IN CERTAIN INVERTEBRATE NERVE FIBERS. Proc. Natl. Acad. Sci. U. S. A. $40,863-70$.

Gershon, R.K., Kondo, K., 1970. Cell interactions in the induction of tolerance: the role of thymic lymphocytes. Immunology $18,723-737$.

Gonzalez, D., Rebolledo, D.L., Correa, L.M., Court, F.A., Cerpa, W., Lipson, K.E., van Zundert, B., Brandan, E., 2018. The inhibition of CTGF/CCN2 activity improves muscle and locomotor function in a murine ALS model. Hum. Mol. Genet. 27, 2913-2926. https://doi.org/10.1093/hmg/ddy204

Gupta, R., Hong, D., Iborra, F., Sarno, S., Enver, T., 2007. NOV (CCN3) Functions as a Regulator of Human Hematopoietic Stem or Progenitor Cells. Science (80-. ). 316, 590593.

Haertel, E., Joshi, N., Hiebert, P., Kopf, M., Werner, S., 2018. Regulatory T cells are required for normal and activin-promoted wound repair in mice. Eur. J. Immunol. 48, 10011013. https://doi.org/10.1002/eji.201747395

Hall, A.O.H., Beiting, D.P., Tato, C.M., John, B., Lombana, C.G., Pritchard, G.H., Silver, J.S., 
Bouladoux, N., Stumhofer, J.S., Harris, T.H., Grainger, J., Tait, E.D., Wagage, S., Roos, D.S., Scott, P., Turka, L.A., Cherry, S., Reiner, S.L., Cua, D., Belkaid, Y., Elloso, M.M., Hunter, C.A., 2013. The cytokines Interleukin 27 and Interferon- $\nu$ promote distinct Treg cell populations required to limit infection-induced pathology. Immunity $37,511-523$. https://doi.org/10.1016/j.immuni.2012.06.014.The

Hall, S.M., 1972. The effect of injections of lysophosphatidyl choline into white matter of the adult mouse spinal cord. J. Cell Sci. 10, 535-546.

Hashimoto, Y., Shindo-Okada, N., Tani, M., Nagamachi, Y., Takeuchi, K., Shiroishi, T., Toma, H., Yokota, J., 1998. Expression of the Elm1 gene, a novel gene of the CCN (connective tissue growth factor, Cyr61/Cef10, and neuroblastoma overexpressed gene) family, suppresses In vivo tumor growth and metastasis of K-1735 murine melanoma cells. J. Exp. Med. 187, 289-96.

Heath, E., Tahri, D., Andermarcher, E., Schofield, P., Fleming, S., Boulter, C.A., 2008.

Abnormal skeletal and cardiac development, cardiomyopathy, muscle atrophy and cataracts in mice with a targeted disruption of the Nov (Ccn3) gene. BMC Dev. Biol. 8, 18. https://doi.org/10.1186/1471-213X-8-18

Hori, S., Nomura, T., Sakaguchi, S., 2003. Control of Regulatory T Cell Development by the Transcription Factor Foxp3. Science (80-. ). 299, 1057-1061. https://doi.org/10.1126/science.1079490

Hoshijima, M., Hattori, T., Aoyama, E., Nishida, T., Yamashiro, T., Takigawa, M., 2012. Roles of heterotypic CCN2/CTGF-CCN3/NOV and homotypic CCN2-CCN2 interactions in expression of the differentiated phenotype of chondrocytes. FEBS J. 279, 3584-3597. https://doi.org/10.1111/j.1742-4658.2012.08717.x

Janune, D., Abd El Kader, T., Aoyama, E., Nishida, T., Tabata, Y., Kubota, S., Takigawa, M., 2017. Novel role of CCN3 that maintains the differentiated phenotype of articular cartilage. J. Bone Miner. Metab. 35, 582-597. https://doi.org/10.1007/s00774-0160793-4

Janune, D., Kubota, S., Nishida, T., Kawaki, H., Perbal, B., lida, S., Takigawa, M., 2011. Novel 
effects of CCN3 that may direct the differentiation of chondrocytes. FEBS Lett. 585, 3033-3040. https://doi.org/10.1016/j.febslet.2011.08.024

Joliot, V., Martinerie, C., Dambrine, G., Plassiart, G., Brisac, M., Crochet, J., Perbal, B., 1992.

Proviral rearrangements and overexpression of a new cellular gene (nov) in myeloblastosis-associated virus type 1-induced nephroblastomas. Mol. Cell. Biol. 12, $10-21$.

Kawaki, H., Kubota, S., Suzuki, A., Lazar, N., Yamada, T., Matsumura, T., Ohgawara, T., Maeda, T., Perbal, B., Lyons, K.M., Takigawa, M., 2008. Cooperative regulation of chondrocyte differentiation by CCN2 and CCN3 shown by a comprehensive analysis of the CCN family proteins in cartilage. J. Bone Miner. Res. 23, 1751-1764.

https://doi.org/10.1359/jbmr.080615

Khodosevich, K., Lazarini, F., vonEngelhardt, J., Kaneko, H., Lledo, P.M., Monyer, H., 2013. Connective Tissue Growth Factor Regulates Interneuron Survival and Information Processing in the Olfactory Bulb. Neuron 79, 1136-1151.

https://doi.org/10.1016/j.neuron.2013.07.011

Kim, K.H., Min, Y.K., Baik, J.H., Lau, L.F., Chaqour, B., Chung, K.C., 2003. Expression of angiogenic factor Cyr61 during neuronal cell death via the activation of c-Jun Nterminal kinase and serum response factor. J. Biol. Chem. 278, 13847-13854. https://doi.org/10.1074/jbc.M210128200

Kim, Y.G., Lee, C.K., Nah, S.S., Mun, S.H., Yoo, B., Moon, H.B., 2007. Human CD4+CD25+ regulatory $T$ cells inhibit the differentiation of osteoclasts from peripheral blood mononuclear cells. Biochem. Biophys. Res. Commun. 357, 1046-1052. https://doi.org/10.1016/j.bbrc.2007.04.042

Kitagawa, Y., Sakaguchi, S., 2017. Molecular control of regulatory T cell development and function. Curr. Opin. Immunol. 49, 64-70. https://doi.org/10.1016/j.coi.2017.10.002

Kotter, M.R., Setzu, A., Sim, F.J., Van Rooijen, N., Franklin, R.J.M., 2001. Macrophage depletion impairs oligodendrocyte remyelination following lysolecithin-induced demyelination. Glia 35, 204-212. https://doi.org/10.1002/glia.1085 
Kucharska, J., Del Río, P., Arango-Gonzalez, B., Gorza, M., Feuchtinger, A., Hauck, S.M., Ueffing, M., 2014. Cyr61 activates retinal cells and prolongs photoreceptor survival in rd1 mouse model of retinitis pigmentosa. J. Neurochem. 130, 227-240. https://doi.org/10.1111/jnc.12704

Kuhlmann, T., Miron, V., Cuo, Q., Wegner, C., Antel, J., Brück, W., 2008. Differentiation block of oligodendroglial progenitor cells as a cause for remyelination failure in chronic multiple sclerosis. Brain 131, 1749-1758. https://doi.org/10.1093/brain/awn096

Kular, L., Rivat, C., Lelongt, B., Calmel, C., Laurent, M., Pohl, M., Kitabgi, P., MelikParsadaniantz, S., Martinerie, C., 2012. NOV/CCN3 attenuates inflammatory pain through regulation of matrix metalloproteinases-2 and -9. J. Neuroinflammation 9, 36. https://doi.org/10.1186/1742-2094-9-36

Kuswanto, W., Burzyn, D., Panduro, M., Wang, K.K., Jang, Y.C., Wagers, A.J., Benoist, C., Mathis, D., 2016. Poor Repair of Skeletal Muscle in Aging Mice Reflects a Defect in Local, Interleukin-33-Dependent Accumulation of Regulatory T Cells. Immunity 44, 355-367. https://doi.org/10.1016/j.immuni.2016.01.009

Lafont, J., Jacques, C., Le Dreau, G., Calhabeu, F., Thibout, H., Dubois, C., Berenbaum, F., Laurent, M., Martinerie, C., 2005. New target genes for NOV/CCN3 in chondrocytes: TGF- $\beta 2$ and type X collagen. J. Bone Miner. Res. 20, 2213-2223. https://doi.org/10.1359/JBMR.050818

Lassmann, H., 2014. Multiple sclerosis: Lessons from molecular neuropathology. Exp. Neurol. 262, 2-7. https://doi.org/10.1016/j.expneurol.2013.12.003

Lau, L.W., Cua, R., Keough, M.B., Haylock-Jacobs, S., Yong, V.W., 2013. Pathophysiology of the brain extracellular matrix: a new target for remyelination. Nat. Rev. Neurosci. 14, 722-729. https://doi.org/10.1038/nrn3550

Le Dréau, G., Nicot, A., Bénard, M., Thibout, H., Vaudry, D., Martinerie, C., Laurent, M., 2010. NOV/CCN3 promotes maturation of cerebellar granule neuron precursors. Mol. Cell. Neurosci. 43, 60-71. https://doi.org/10.1016/j.mcn.2009.02.011

Lee, Y., Morrison, B.M., Li, Y., Lengacher, S., Farah, M.H., Hoffman, P.N., Liu, Y., Tsingalia, A., 
Jin, L., Zhang, P.-W., Pellerin, L., Magistretti, P.J., Rothstein, J.D., 2012. Oligodendroglia metabolically support axons and contribute to neurodegeneration. Nature 487, 443448. https://doi.org/10.1038/nature11314

Legroux, L., Arbour, N., 2016. Multiple Sclerosis and T Lymphocytes : An Entangled Story T Lymphocytes : Key Cells of the Adaptive Immune Responses 10, 528-546. https://doi.org/10.1007/s11481-015-9614-0.Multiple

Lin, C.G., Leu, S.J., Chen, N., Tebeau, C.M., Lin, S.X., Yeung, C.Y., Lau, L.F., 2003. CCN3 (NOV) is a novel angiogenic regulator of the CCN protein family. J. Biol. Chem. 278, 2420024208. https://doi.org/10.1074/jbc.M302028200

Lin, Z., Natesan, V., Shi, H., Hamik, A., Kawanami, D., Hao, C., Mahabaleshwar, G.H., Wang, W., Jin, Z.G., Atkins, G.B., Firth, S.M., Rittié, L., Perbal, B., Jain, M.K., 2010. A novel role of CCN3 in regulating endothelial inflammation. J. Cell Commun. Signal. 4, 141-153. https://doi.org/10.1007/s12079-010-0095-x

Lindner, M., Trebst, C., Heine, S., Skripuletz, T., Koutsoudaki, P.N., Stangel, M., 2008. The chemokine receptor CXCR2 is differentially regulated on glial cells in vivo but is not required for successful remyelination after cuprizone-induced demyelination. Glia 56, 1104-1113. https://doi.org/10.1002/glia.20682

Liu, J., Ren, Y., Kang, L., Zhang, L., 2014. Overexpression of CCN3 inhibits inflammation and progression of atherosclerosis in apolipoprotein E-deficient mice. PLoS One 9, 3-9. https://doi.org/10.1371/journal.pone.0094912

Malik, A.R., Liszewska, E., Jaworski, J., 2015. Matricellular proteins of the Cyr61/CTGF/NOV (CCN) family and the nervous system. Front. Cell. Neurosci. 9, 1-13. https://doi.org/10.3389/fncel.2015.00237

Malik, A.R., Urbanska, M., Gozdz, A., Swiech, L.J., Nagalski, A., Perycz, M., Blazejczyk, M., Jaworski, J., 2013. Cyr61, a matricellular protein, is needed for dendritic arborization of hippocampal neurons. J. Biol. Chem. 288, 8544-8559.

https://doi.org/10.1074/jbc.M112.411629

Marchal, P.O., Kavvadas, P., Abed, A., Kazazian, C., Authier, F., Koseki, H., Hiraoka, S., Boffa, 
J.J., Martinerie, C., Chadjichristos, C.E., 2015. Reduced NOV/CCN3 expression limits inflammation and interstitial renal fibrosis after obstructive nephropathy in mice. PLoS One 10, 1-12. https://doi.org/10.1371/journal.pone.0137876

Maryvonne, L., Gwenvaël, L.D., Xavier, G., Cécile, L.E., Amélie, S., Olivier, G., Cécile, M., Maria, M., 2012. Temporal and spatial expression of CCN3 during retina development. Dev. Neurobiol. 72, 1363-1375. https://doi.org/10.1002/dneu.20994

Matsushita, Y., Sakamoto, K., Tamamura, Y., Shibata, Y., Minamizato, T., Kihara, T., Ito, M., Katsube, K.I., Hiraoka, S., Koseki, H., Harada, K., Yamaguch, A., 2013. CCN3 protein participates in bone regeneration as an inhibitory factor. J. Biol. Chem. 288, 1997319985. https://doi.org/10.1074/jbc.M113.454652

Mei, F., Fancy, S.P.J., Shen, Y.A.A., Niu, J., Zhao, C., Presley, B., Miao, E., Lee, S., Mayoral, S.R., Redmond, S.A., Etxeberria, A., Xiao, L., Franklin, R.J.M., Green, A., Hauser, S.L., Chan, J.R., 2014. Micropillar arrays as a high-throughput screening platform for therapeutics in multiple sclerosis. Nat. Med. 20, 954-960.

https://doi.org/10.1038/nm.3618

Mi, S., Hu, B., Hahm, K., Luo, Y., Kam Hui, E.S., Yuan, Q., Wong, W.M., Wang, L., Su, H., Chu, T.-H., Guo, J., Zhang, W., So, K.-F., Pepinsky, B., Shao, Z., Graff, C., Garber, E., Jung, V., Wu, E.X., Wu, W., 2007. LINGO-1 antagonist promotes spinal cord remyelination and axonal integrity in MOG-induced experimental autoimmune encephalomyelitis. Nat. Med. 13, 1228-1233. https://doi.org/10.1038/nm1664

Minamizato, T., Sakamoto, K., Liu, T., Kokubo, H., Katsube, K. ichi, Perbal, B., Nakamura, S., Yamaguchi, A., 2007. CCN3/NOV inhibits BMP-2-induced osteoblast differentiation by interacting with BMP and Notch signaling pathways. Biochem. Biophys. Res. Commun. 354, 567-573. https://doi.org/10.1016/j.bbrc.2007.01.029

Miron, V.E., Boyd, A., Zhao, J.-W., Yuen, T.J., Ruckh, J.M., Shadrach, J.L., van Wijngaarden, P., Wagers, A.J., Williams, A., Franklin, R.J.M., ffrench-Constant, C., 2013. M2 microglia and macrophages drive oligodendrocyte differentiation during CNS remyelination. Nat. Neurosci. 16, 1211-8. https://doi.org/10.1038/nn.3469 
Mock, J.R., Garibaldi, B.T., Aggarwal, N.R., Jenkins, J., Limjunyawong, N., Singer, B.D., Chau, E., Rabold, R., Files, D., Sidhaye, V., Mitzner, W., Wagner, E.M., King, L.S., D’Alessio, F.R., 2014. Foxp3+ Regulatory T Cells Promote Lung Epithelial Proliferation. Mucosal Immunol 7, 1440-1451. https://doi.org/10.3109/10641955.2015.1046604.Association

Najm, F.J., Madhavan, M., Zaremba, A., Shick, E., Karl, R.T., Factor, D.C., Miller, T.E., Nevin, Z.S., Kantor, C., Sargent, A., Quick, K.L., Schlatzer, D.M., Tang, H., Papoian, R., Brimacombe, K.R., Shen, M., Boxer, M.B., Jadhav, A., Robinson, A.P., Podojil, J.R., Miller, S.D., Miller, R.H., Tesar, P.J., 2015. Drug-based modulation of endogenous stem cells promotes functional remyelination in vivo. Nature 522, 216-220. https://doi.org/10.1038/nature14335

Nosbaum, A., Prevel, N., Truong, H.-A., Mehta, P., Ettinger, M., Scharschmidt, T.C., Ali, N.H., Pauli, M.L., Abbas, A.K., Rosenblum, M.D., 2016. Cutting Edge: Regulatory T Cells Facilitate Cutaneous Wound Healing. J. Immunol. 196, 2010-2014. https://doi.org/10.4049/jimmunol.1502139

O’Brien, T.P., Yang, G.P., Sanders, L., Lau, L.F., 1990. Expression of cyr61, a growth factorinducible immediate-early gene. Mol. Cell. Biol. 10, 3569-77.

Ohkawa, Y., Ohmi, Y., Tajima, O., Yamauchi, Y., Furukawa, K., Furukawa, K., 2011. Wisp2/CCN5 up-regulated in the central nervous system of GM3-only mice facilitates neurite formation in Neuro2a cells via integrin-Akt signaling. Biochem. Biophys. Res. Commun. 411, 483-489. https://doi.org/10.1016/j.bbrc.2011.06.118

Oldenhove, G., Bouladoux, N., Wohlfert, E.A., Hall, J.A., Chou, D., Dos santos, L., O’Brien, S., Blank, R., Lamb, E., Natarajan, S., Kastenmayer, R., Hunter, C., Grigg, M.E., Belkaid, Y., 2009. Decrease of Foxp3+Treg Cell Number and Acquisition of Effector Cell Phenotype during Lethal Infection. Immunity 31, 772-786. https://doi.org/10.1016/j.immuni.2009.10.001

Ouellet, V., Siegel, P.M., 2012. CCN3 modulates bone turnover and is a novel regulator of skeletal metastasis. J. Cell Commun. Signal. 6, 73-85. https://doi.org/10.1007/s12079012-0161-7 
Park, M., Baek, I.J., Kim, H., Woo, D.K., Park, Y.J., Shim, S., 2015. CCN3 overexpression inhibits growth of callosal projections via upregulation of RAB25. Biochem. Biophys. Res. Commun. 461, 456-462. https://doi.org/10.1016/j.bbrc.2015.04.016

Patani, R., Balaratnam, M., Vora, A., Reynolds, R., 2007. Remyelination can be extensive in multiple sclerosis despite a long disease course. Neuropathol. Appl. Neurobiol. 33, 277-287. https://doi.org/10.1111/j.1365-2990.2007.00805.x

Pennica, D., Swanson, T.A., Welsh, J.W., Roy, M.A., Lawrence, D.A., Lee, J., Brush, J., Taneyhill, L.A., Deuel, B., Lew, M., Watanabe, C., Cohen, R.L., Melhem, M.F., Finley, G.G., Quirke, P., Goddard, A.D., Hillan, K.J., Gurney, A.L., Botstein, D., Levine, A.J., 1998. WISP genes are members of the connective tissue growth factor family that are upregulated in wnt-1-transformed cells and aberrantly expressed in human colon tumors. Proc. Natl. Acad. Sci. U. S. A. 95, 14717-22.

Perbal, B., 2018. The concept of the CCN protein family revisited: a centralized coordination network. J. Cell Commun. Signal. 12, 3-12. https://doi.org/10.1007/s12079-018-0455-5

Perbal, B., 2013. CCN proteins: A centralized communication network. J. Cell Commun. Signal. 7, 169-177. https://doi.org/10.1007/s12079-013-0193-7

Perbal, B., 2004. CCN proteins: Multifunctional signalling regulators. Lancet 363, 62-64. https://doi.org/10.1016/S0140-6736(03)15172-0

Perbal, B., Takigawa, M., 2005. CCN Proteins: A new family of cell growth and differentiation regulators. PUBLISHED BY IMPERIAL COLLEGE PRESS AND DISTRIBUTED BY WORLD SCIENTIFIC PUBLISHING CO. https://doi.org/10.1142/p384

Plaisted, W.C., Zavala, A., Hingco, E., Tran, H., Coleman, R., Lane, T.E., Loring, J.F., Walsh, C.M., 2016. Remyelination is correlated with regulatory T cell induction following human embryoid body-derived neural precursor cell transplantation in a viral model of multiple sclerosis. PLoS One 11, 1-20. https://doi.org/10.1371/journal.pone.0157620

Plemel, J.R., Liu, W.-Q., Yong, V.W., 2017. Remyelination therapies: a new direction and challenge in multiple sclerosis. Nat. Rev. Drug Discov. 16, 617-634. https://doi.org/10.1038/nrd.2017.115 
Pugliatti, M., Sotgiu, S., Rosati, G., 2002. The worldwide prevalence of multiple sclerosis.

Clin. Neurol. Neurosurg. 104, 182-191. https://doi.org/10.1016/S0303-8467(02)000367

Raine, C.S., Wu, E., 1993. Multiple sclerosis: remyelination in acute lesions. J. Neuropathol. Exp. Neurol. 52, 199-204.

Raposo, C., Graubardt, N., Cohen, M., Eitan, C., London, A., Berkutzki, T., Schwartz, M., 2014. CNS Repair Requires Both Effector and Regulatory T Cells with Distinct Temporal and Spatial Profiles. J. Neurosci. 34, 10141-10155. https://doi.org/10.1523/JNEUROSCI.0076-14.2014

Roddy, K.A., Boulter, C.A., 2015. Targeted mutation of NOV/CCN3 in mice disrupts joint homeostasis and causes osteoarthritis-like disease. Osteoarthr. Cartil. 23, 607-615. https://doi.org/10.1016/j.joca.2014.12.012

Ruckh, J.M., Zhao, J.W., Shadrach, J.L., Van Wijngaarden, P., Rao, T.N., Wagers, A.J., Franklin, R.J.M., 2012. Rejuvenation of regeneration in the aging central nervous system. Cell Stem Cell 10, 96-103. https://doi.org/10.1016/j.stem.2011.11.019

Rydziel, S., Stadmeyer, L., Zanotti, S., Durant, D., Smerdel-Ramoya, A., Canalis, E., 2007. Nephroblastoma overexpressed (Nov) inhibits osteoblastogenesis and causes osteopenia. J. Biol. Chem. 282, 19762-19772. https://doi.org/10.1074/jbc.M700212200

Ryseck, R.P., Macdonald-Bravo, H., Mattéi, M.G., Bravo, R., 1991. Structure, mapping, and expression of fisp-12, a growth factor-inducible gene encoding a secreted cysteine-rich protein. Cell Growth Differ. 2, 225-33.

Sakaguchi, S., 2000. Regulatory T cells: Key controllers of immunologic self-tolerance. Cell 101, 455-458. https://doi.org/10.1016/S0092-8674(00)80856-9

Sakaguchi, S., Sakaguchi, N., Asano, M., Itoh, M., Toda, M., 1995. Immunologic self-tolerance maintained by activated T cells expressing IL-2 receptor alpha-chains (CD25). Breakdown of a single mechanism of self-tolerance causes various autoimmune diseases. J. Immunol. 155, 1151-64. 
Sakamoto, K., Yamaguchi, S., Ando, R., Miyawaki, A., Kabasawa, Y., Takagi, M., Li, C.L., Perbal, B., Katsube, K., 2002. The Nephroblastoma Overexpressed Gene (NOV/ccn3) Protein Associates with Notch1 Extracellular Domain and Inhibits Myoblast Differentiation via Notch Signaling Pathway. J. Biol. Chem. 277, 29399-29405. https://doi.org/10.1074/jbc.M203727200

Saxena, A., Dobaczewski, M., Rai, V., Haque, Z., Chen, W., Li, N., Frangogiannis, N.G., 2014. Regulatory $T$ cells are recruited in the infarcted mouse myocardium and may modulate fibroblast phenotype and function. AJP Hear. Circ. Physiol. 307, H1233-H1242. https://doi.org/10.1152/ajpheart.00328.2014

Schwartz, M., Moalem, G., Leibowitz-Amit, R., Cohen, I.R., 1999. Innate and adaptive immune responses can be beneficial for CNS repair. Trends Neurosci. 22, 295-299. https://doi.org/10.1016/S0166-2236(99)01405-8

Setzu, A., Lathia, J.D., Zhao, C., Wells, K., Rao, M.S., ffrench-Constant, C., Franklin, R.J.M., 2006. Inflammation stimulates myelination by transplanted oligodendrocyte precursor cells. Glia 54, 297-303. https://doi.org/10.1002/glia.20371

Shevach, E.M., 2018. Foxp3+T regulatory cells: Still many unanswered Questions-A perspective after 20 years of study. Front. Immunol. 9, 1-9. https://doi.org/10.3389/fimmu.2018.01048

Sim, F.J., Zhao, C., Penderis, J., Franklin, R.J.M., 2002. The age-related decrease in CNS remyelination efficiency is attributable to an impairment of both oligodendrocyte progenitor recruitment and differentiation. J. Neurosci. 22, 2451-9. https://doi.org/20026217

Sospedra, M., Martin, R., 2016. Immunology of Multiple Sclerosis. Semin. Neurol. 36, 115127. https://doi.org/10.1055/s-0036-1579739

Stritt, C., Stern, S., Harting, K., Manke, T., Sinske, D., Schwarz, H., Vingron, M., Nordheim, A., Knöll, B., 2009. Paracrine control of oligodendrocyte differentiation by SRF-directed neuronal gene expression. Nat. Neurosci. 12, 418-427. https://doi.org/10.1038/nn.2280 
Su, B.Y., Cai, W.Q., Zhang, C.G., Martinez, V., Lombet, A., Perbal, B., 2001. The expression of ccn3 (nov) RNA and protein in the rat central nervous system is developmentally regulated. Mol. Pathol. 54, 184-91.

Trapp, B.D., Peterson, J., Ransohoff, R.M., Rudick, R., Mörk, S., Bö, L., 1998. Axonal Transection in the Lesions of Multiple Sclerosis. N. Engl. J. Med. 338, 278-285. https://doi.org/10.1056/NEJM199801293380502

Viglietta, V., Baecher-Allan, C., Weiner, H.L., Hafler, D.A., 2004. Loss of Functional Suppression by $\mathrm{CD} 4{ }^{+} \mathrm{CD} 25{ }^{+}$Regulatory T Cells in Patients with Multiple Sclerosis. J. Exp. Med. 199, 971-979. https://doi.org/10.1084/jem.20031579

Wang, S., Zhong Chong, Z., Chen Shang, Y., Maiese, K., 2012. Wnt1 Inducible Signaling Pathway Protein 1 (WISP1) Blocks Neurodegeneration through Phosphoinositide 3 Kinase/Akt1 and Apoptotic Mitochondrial Signaling Involving Bad, Bax, Bim, and Bcl-xL. Curr. Neurovasc. Res. 9, 20-31. https://doi.org/10.2174/156720212799297137

Wang, X., He, H., Wu, X., Hu, J., Tan, Y., 2014. Promotion of dentin regeneration via CCN3 modulation on Notch and BMP signaling pathways. Biomaterials 35, 2720-2729. https://doi.org/10.1016/j.biomaterials.2013.12.029

Weirather, J., Hofmann, U.D.W., Beyersdorf, N., Ramos, G.C., Vogel, B., Frey, A., Ertl, G., Kerkau, T., Frantz, S., 2014. Foxp3+ CD4+ T cells improve healing after myocardial infarction by modulating monocyte/macrophage differentiation. Circ. Res. 115, 55-67. https://doi.org/10.1161/CIRCRESAHA.115.303895

Williams, A., Piaton, G., Aigrot, M.S., Belhadi, A., Théaudin, M., Petermann, F., Thomas, J.L., Zalc, B., Lubetzki, C., 2007. Semaphorin 3A and 3F: Key players in myelin repair in multiple sclerosis? Brain 130, 2554-2565. https://doi.org/10.1093/brain/awm202

Wolswijk, G., 2002. Oligodendrocyte precursor cells in the demyelinated multiple sclerosis spinal cord. Brain 125, 338-349. https://doi.org/10.1093/brain/awf031

Woodruff, R.H., Fruttiger, M., Richardson, W.D., Franklin, R.J.M., 2004. Platelet-derived growth factor regulates oligodendrocyte progenitor numbers in adult CNS and their response following CNS demyelination. Mol. Cell. Neurosci. 25, 252-262. 
https://doi.org/10.1016/j.mcn.2003.10.014

Yamasaki, R., Lu, H., Butovsky, O., Ohno, N., Rietsch, A.M., Cialic, R., Wu, P.M., Doykan, C.E., Lin, J., Cotleur, A.C., Kidd, G., Zorlu, M.M., Sun, N., Hu, W., Liu, L., Lee, J.-C., Taylor, S.E., Uehlein, L., Dixon, D., Gu, J., Floruta, C.M., Zhu, M., Charo, I.F., Weiner, H.L., Ransohoff, R.M., 2014. Differential roles of microglia and monocytes in the inflamed central nervous system. J. Exp. Med. 211, 1533-1549. https://doi.org/10.1084/jem.20132477

Young, K.M., Psachoulia, K., Tripathi, R.B., Dunn, S.J., Cossell, L., Attwell, D., Tohyama, K., Richardson, W.D., 2013. Oligodendrocyte dynamics in the healthy adult CNS: Evidence for myelin remodeling. Neuron 77, 873-885.

https://doi.org/10.1016/j.neuron.2013.01.006

Zaiss, M.M., Frey, B., Hess, A., Zwerina, J., Luther, J., Nimmerjahn, F., Engelke, K., Kollias, G., Hunig, T., Schett, G., David, J.-P., 2010a. Regulatory T Cells Protect from Local and Systemic Bone Destruction in Arthritis. J. Immunol. 184, 7238-7246.

https://doi.org/10.4049/jimmunol.0903841

Zaiss, M.M., Sarter, K., Hess, A., Engelke, K., Böhm, C., Nimmerjahn, F., Voll, R., Schett, G., David, J.P., 2010b. Increased bone density and resistance to ovariectomy-induced bone loss in FoxP3-transgenic mice based on impaired osteoclast differentiation. Arthritis Rheum. 62, 2328-2338. https://doi.org/10.1002/art.27535

Zhang, R., Averboukh, L., Zhu, W., Zhang, H., Jo, H., Dempsey, P.J., Coffey, R.J., Pardee, A.B., Liang, P., 1998. Identification of rCop-1, a new member of the CCN protein family, as a negative regulator for cell transformation. Mol. Cell. Biol. 18, 6131-41. 
SP-IGFBP - VWC $\overbrace{}^{\text {hinges }} \mathrm{TSP1}-\mathrm{CT}$ 


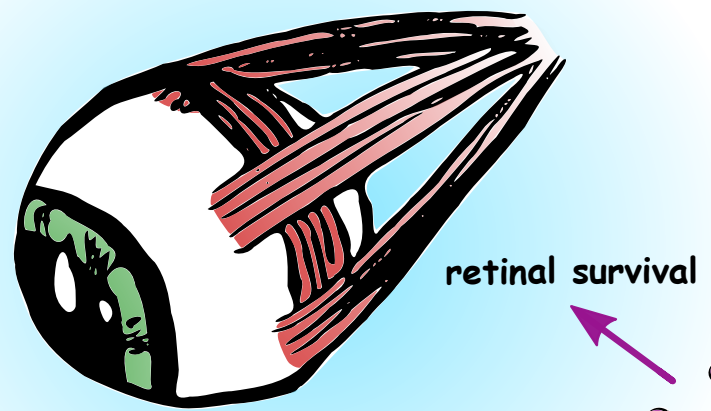

retinal development

neurite formation, growth \& dendritic branching
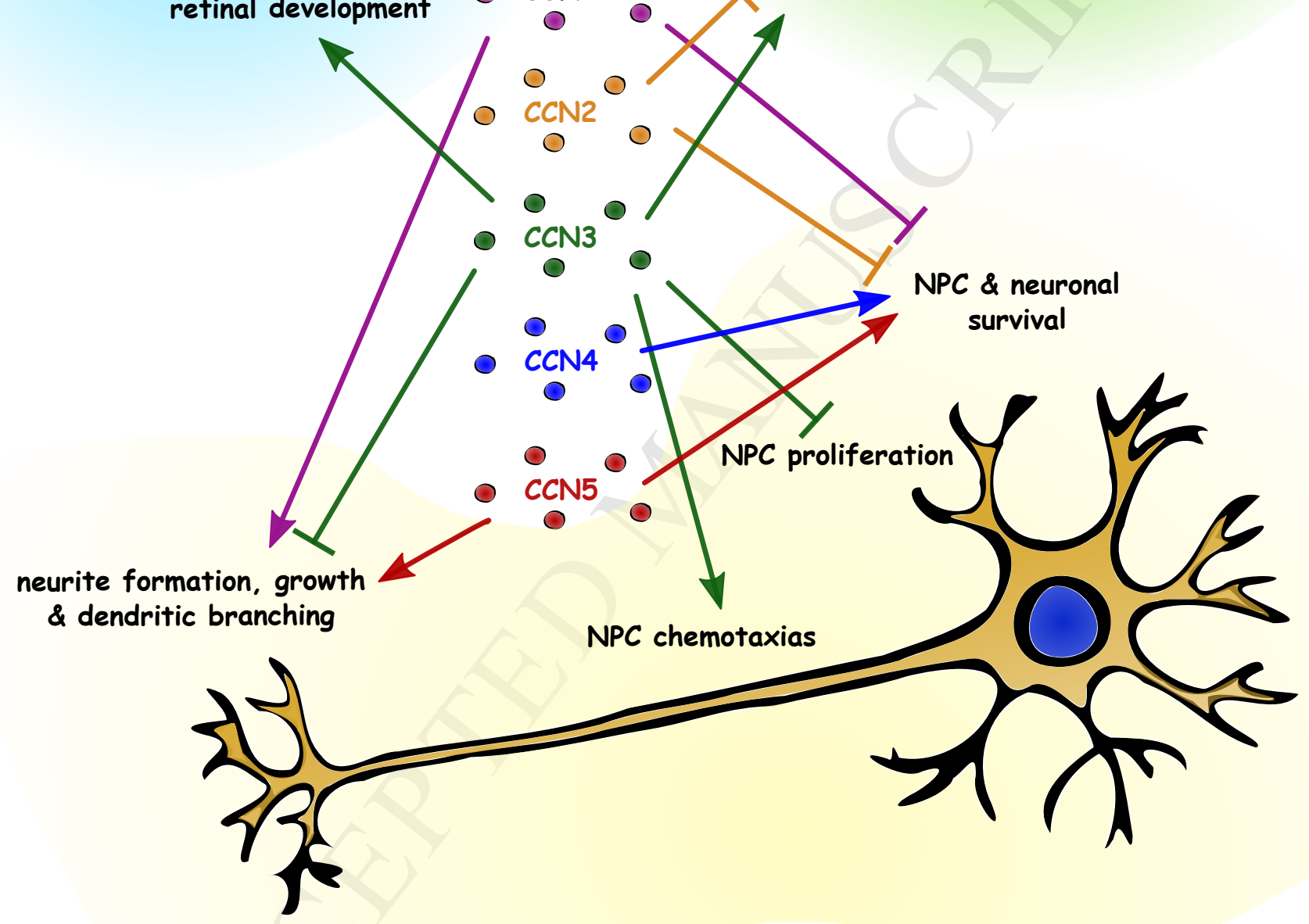

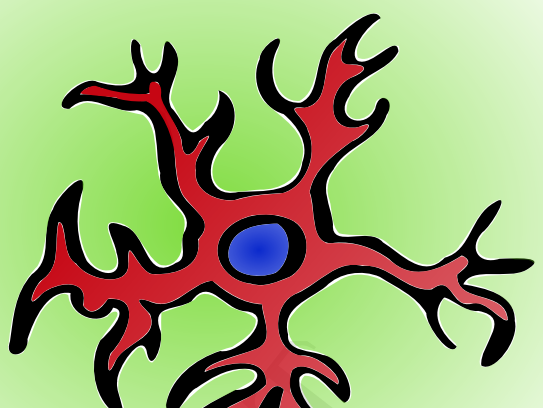

OPC differentiation

\& myelination 